\title{
Website-Based Green School on Fashion Education and Training
}

\author{
Miftahul Annisah Nurfitria ${ }^{1 *}$, Didik Hariyanto ${ }^{1}$, Widihastuti ${ }^{2}$ \\ ${ }^{1}$ Technology and Vocational Education Department, Graduate School of Universitas Negeri Yogyakarta, Indonesia \\ ${ }^{2}$ Educational Research and Education Department, Graduate School of Universitas Negeri Yogyakarta, Indonesia \\ *Corresponding author.Email: miftahulannisah.2020@student.uny.ac.id
}

\begin{abstract}
The development of technology and digitization is a disruptive factor in the structure of human life. Education aspects are among those affected. Innovations in implementation must be carried out on an ongoing basis. The research was conducted with literature reviews. The research was carried out with journals and books then compared and analyzed in an empirical study to get the pattern of theory implementation in green schools in fashion education. The results in the form of strategies and indicators of success of website-based implementation. The implementation is the program that utilizes the website as e-learning in fashion education and training as an environmentally friendly program. Webbased schools in fashion training and educational institutions are alternatives and solutions in organizing fashion training in the era of digitalization, the industrial revolution 4.0 and Covid-19 pandemic.
\end{abstract}

Keywords: education and training, disruption, green school, website

\section{INTRODUCTION}

The changes that occurred due to the Covid-19 pandemic and the 4.0 industrial revolution resulted in a rapid disruption to the education and training sector in Indonesia [1]. This is mainly triggered by digitalization and technological developments. As a result, new complex problems and challenges arise in all aspects of life. Society is indirectly forced to replace the old system with a new system so that there is a balance and human life continues to run according to the needs, demands and conditions that occur. New things are difficult for the community to adapt because they require a long time and education. Living systems that are carried out remotely are an alternative in overcoming problems due to the Covid-19 pandemic that occurred by utilizing digitalization and technological sophistication.

Revolution is a major change that occurs in the system of life, including the economic system and the social structure of society. Change is triggered by technological developments and new perspectives on problems that occur in the world [2]. The existence of this revolution is caused by the rapid development of technology and occurs throughout the world. There are four stages of the industrial revolution. The digital revolution with the invention of the internet, censorship, artificial intelligence, and industrial automation is part of the fourth industrial revolution [3].

The Covid-19 pandemic is currently spreading all over the world. This disease is caused by a corona virus which infects the respiratory tract of the sufferer. Its easy transmission makes people have to be more vigilant in various ways. One of them is by maintaining distance and direct interaction. Therefore, many human activities are carried out without any direct social interaction [4]. The 4.0 industrial revolution that is being talked about is coupled with the Covid-19 pandemic in the 21 st century resulted in the process of changing all aspects of life being faster and very drastic. The structure and way of working remotely through space and time to find new skills independently becomes a solution alternative. The new system relies heavily on decentralized technology and digitization. Changes that lead to a new system have been seen since before the Covid-19 pandemic occurred, but in society there is a faster transition after the Covid19 pandemic. One of them is the world of vocational 
education which must adapt quickly, especially the industrial world has already transformed with digitalbased conditions. Mastery of skills and good competency certification that shows the level of one's skills in vocational education must also be possessed by students. This is a challenge for educational and training institutions to determine how to carry out learning in accordance with the all-digital pandemic conditions [5].

The characteristics of education in every era always change according to the situation and conditions. Education in the 4.0 era carries several well-known concepts, including self-directed learning and long-life learning [6]. The learning process in the 4.0 era emphasizes more on the independent learning process. In the learning process, students are encouraged to find their own learning resources, design their own learning, discuss, and experiment by utilizing technology, information sources and available facilities. This learning process is called the andragogy learning process or adult learning [7]. Learning objectives and strategies must be clearly defined so that students can be more focused. Learning carried out by students must also be continuous to improve skills, knowledge, and qualifications so that changes and developments will occur in students [8].

The existence of Covid-19, the industrial revolution 4.0 and digitalization due to technological developments can trigger environmental pollution. New problems as a result of these polluted conditions will also appear in life. Concern for the environment as a form of concern for nature as an ecosystem where human life needs to be done, this is because the balance of the ecosystem of life will have an impact on the process of human life. In the world of education, the character of caring for the environment needs to be integrated into the subject matter so as to form an understanding, attitude and behavior of caring for the environment which is implemented in various human activities such as production activities and consumption activities. All activities carried out by humans will have an impact on the environment, both as providers of resources to meet needs and as objects affected by human activities [9].

The ambiguity of the vocational education and training system due to the Covid-19 pandemic has hit aspects of education throughout the world, both formal and nonformal [10]. The conditions that create a dilemma for policy makers to carry out education and training directly are still protracted. Moreover, vocational education will be maximized if it is held directly. And this fashion training must be held on a digitally and adapt to pandemic conditions. In addition to distance, education and training must also be held on an ongoing basis so that it will produce quality human resources and are ready to work.

Vocational education is education to develop a person's vocational so that they have the capacity or capability to be assigned or given orders to do work or carry out certain positions. Vocational Education learning is gradually oriented to work work-oriented learning then linked to work-connected learning tasks or work and integrated with work-integrated learning work [11]. Vocational education will be very effective if it is held in a sustainable manner and becomes a solution to environmental and social problems. Green school is a school concept designed as an environmentally friendly school. The green school movement focuses on an approach that involves school residents (students, teachers, and the community) to protect the environment including the use of resources and the school's environmental footprint, as well as motivating students to address environmental problems by finding solutions in local and global scope. Green schools will shape students' mindsets and improve sustainable behavior attitudes [12]. Based on these things, research questions can be obtained, namely what are the strategies and indicators of success in the implementation of websitebased fashion education and training institutions.

\section{METODHS}

This study aims to determine the strategies and indicators of success in implementing website-based green school in educational institutions and fashion training. This research is a qualitative research with a literature review research method. Literature searches were carried out through Springerlink, Science Direct, Scopus, Proquest, and Google Scholar. The journals obtained were compared and analyzed in empirical studies in order to obtain theories on the implementation of green schools in educational institutions and fashion training. The articles searched were 5 on Springerlink, 7 on Science Direct, 5 on Scopus, 5 on Proquest and 5 on Google Scholar. The search results articles were screened and produced 3 articles that were in accordance with the research. The data obtained were collected, adjusted and analyzed.

\section{RESULT AND DISCUSSION}

Vocational learning in the era of disruption in the $21^{\text {st }}$ Century requires learning designs towards the projection of workforce competency development with a profile that is in accordance with the needs of the Industry 4.0 era without leaving conventional needs that are still ongoing and needed in the field. The $21^{\text {st }}$ Century vocational learning leads to the development of motoric skill competencies, intellectual skills, and mental skills as a whole, supported by comprehensive work knowledge, morals and work attitudes [13]. Fashion education and training is one of the vocational fields that are part of vocational education. The concepts, principles, and objectives of vocational education must be applied to the process of providing fashion education and training. Learning strategies and indicators of learning success at educational institutions and fashion training will be very important to pay attention to for the sustainability of the program in accordance with the needs of the industrial revolution 4.0 and digitalization. The Covid-19 pandemic is a major obstacle in the 
implementation of direct vocational learning, so learning innovations that can be carried out remotely are needed. The website-based green school concept is an alternative that can be held in educational and training institutions.

The learning approach in the 4.0 era, namely technology provides concepts and tools for communication, mobility, and forms of instructional learning design. One of them is through web-based multimedia. Independent and distance learning open up a very broad concept of learning with the involvement of the instructor as a mentor. Learning can be done with blended learning that is combining face-to-face with website-based learning. Virtual simulations, didactic teaching, discussions, and independent learning models can also be more effectively held on a website-based form. The learning process creates interactions that involve learning skills, critical thinking, analytical skills and skills in concluding the material. The results of the learning process will create learning experiences that interact and contribute wherever they are. Analytical skills, time management, leadership, priorities, problem solving and critical thinking will be formed from the learning process carried out. Education can take place semiinteractive and in accordance with the learning style of revolution 4.0 [14].

Web-based learning is also known as distance learning. Distance learning for adults is mostly done independently, providing real, reflective, observation, experimental, and abstract experiences. Systemregistered students will receive online instruction. Study group members separated by distance and time. The main point that characterizes distance learning is the difference in time and location between study groups that can interact with each other in discussion forums. This distance learning process can be done at the same time (synchronous) or different (asynchronous) [15]. Learning models in fashion education and training can be effectively carried out using blended learning and project models. Website-based blended learning models can be done with a combination of 50/50, 75/25, and $25 / 75$. The combination is applied depending on the required competency analysis, subject objectives, student characteristics, characteristics of student abilities and available resources [16]. The form of implementing theoretical learning can be done using website media, while practical learning can use project-based learning. Feedback and practical learning are carried out face to face. The blended learning model in fashion education and training is effectively implemented because the blended learning model has advantages such as students interacting directly with the content of learning, being able to interact with friends, discussing groups and exchanging opinions, accessing e-libraries or virtual classes, online assessments, e-learning. Tuitions, Accessing and maintaining learning blogs, Online seminars (webinars), Viewing expert lecturers on YouTube, Learning online through video and audio, and Virtual laboratories [17].
Education and training is a series of activities designed to improve skills, knowledge, experience, or change the attitude of an individual or group in carrying out certain tasks. In a training has several characteristics, namely: (1) planned intentionally, (2) there are goals to be achieved, (3) there are participants (target groups) and training, (4) there are practical learning activities, (5) content learning and practice emphasizes the expertise or skills of a particular job, (6) is carried out in a relatively short time, and (7) there is a place to learn and practice [18]. Fashion education and training can be held in the concept of green school. Green school is a school concept that integrates the values of nature conservation, social justice, development, democracy, and social change. The focus of the program implemented is on ESD (education for sustainable development). Curriculum, learning models, forms of learning programs, and learning materials used are directed at the focus of continuing education. The essence of green school is a learning experience and sensitivity to the environment. The green school concept helps reorient continuing education through policy or curriculum training, human resource development, sustainable project management, partnership development, and strengthening the role of government [12]. Green school at educational institutions and training in fashion is implemented with learning that utilizes used goods such as the use of used paper in the practice process of making fashion patterns, making fashion products that use leftover fabrics from sewing, and utilizing used clothes into new fashion products. Learning activities are also carried out by minimizing the use of paper in the administrative process.

Green schools in educational institutions and fashion training can shape behavior that reflects environmental care. Students' attitudes, knowledge and behavior will be formed as the program activity process runs. This impact will affect the mindset of students so that students will have a concern for the environment. Green school in educational and training institutions will have a more effective impact if it is applied to students as early as possible [12]. The success rate of implementing a website-based green school program in an educational and training institution is influenced by several factors including people's characteristics, environmental characteristics, job characteristics and policies, and management practices [19]. The characteristics of a conducive and sensitive environment will form good work and character in solving problems. Human resources as quality managers will bring optimal performance of educational and training institutions. Job characteristics and policies will bring the performance of educational institutions and fashion training to faster in realizing the main goal of the green school program in sustainable website-based fashion education and training. Planned and structured management will facilitate the program implementation process.

Success in program implementation will be determined by the management of resource management, especially 
its performance. Effective human resources will produce effective performance and can be assessed from several indicators, namely (1) effective use of time (2) selforganization, (3) doing work properly, (4) complying with work instructions, (5) effectiveness in communication, and (6) effectiveness of education. While the implementation of the program will be called effective if the program is held to produce graduates who have competence according to the needs of the fashion industry and have a level of environmental concern [20].

\section{CONCLUSION}

Based on this research, it can be concluded that the strategy of implementing distance education and training in clothing can be implemented effectively with the website-based green school concept. The learning model can be applied with blended learning and project-based learning. The combination of two learning models can be applied to the website-based green school concept. The success of implementating learning with green school can be seen in graduates who have competence according to the needs of the fashion industry and a high level of environmental awareness.

\section{REFERENCES}

[1] M.H.F. Ali, Transformasi dan digitalisasi pendidikan dimasa pandemi, Pros. Semin. Nas. Pendidik., 2021, pp. 121-127,

[2] K. Schwab, The fourth industrial revolution. switzerland: World Economic Forum, 2017.

[3] K. Schwab, The fourth industrial revolution. switzerland: World Economic Forum, 2016.

[4] N. Ullah, The world after covid -19 , in covid-19 pandemic update 2020, Royal Book Publishing, 2020, pp. 248-253.

[5] R.H. Hilma Erliana, I. Jaya, Lutfi, Nuthihar, Safrizal, R. Wahdaniah, Vocational student's perception of online learning during the covid-19 pandemic, J. Pendidik. Teknol. dan Kejuru., vol. 27, no. 1, pp. 57-65, 2021, doi: 10.1007/s12098020-03327-7.

[6] E. Pratidhina, Education 4. 0: Pergeseran pendidikan sebagai konsekuensi revolusi industri 4 . 0, Kaji. Mata Kuliah Umum, vol. 20, no. 1, pp. 112, 2020, doi: 10.21831/hum.v20i1.29290.1-12.

[7] Ä. Leijen, K. Saks, Distinguishing self-directed and self-regulated learning and measuring them in the e-learning context, Procedia - Soc. Behav. Sci., vol. 112, no. Iceepsy 2013, pp. 190-198, 2014, doi: 10.1016/j.sbspro.2014.01.1155.

[8] A.W.L. Liau, G.B. Sai, Emotional literacy, lifelong learning, and global citizenship education for adult distance learners. New York, London: Routledge, 2021.

[9] Rahmatullah, Eco-culture: suatu model pembelajaran ekonomi berorientasi peduli lingkungan, JEKPEND J. Ekon. dan Pendidik., vol. 4, no. 1, p. 99, 2021, doi: 10.26858/jekpend.v4i1.16334.

[10] M.J. Sá, S. Serpa, The covid-19 Pandemic as an opportunity to foster the sustainable development of teaching in higher education, Sustain., vol. 12, no. 20, pp. 1-16, 2020, doi: 10.3390/su12208525.

[11] P. Sudira, TVET abad xxi filosofi, konsep, dan strategi pembelajaran vokasional, 2nd ed. Yogyakarta, 2016.

[12] M.F. Taşar, Impact of the eco-schools program on education for sustainable development in turkey. melbourne, Australia, 2020.

[13] P. Sudira, Metodologi pembelajaran vocational: inovasi, teori dan praksis. 2018.

[14] J. Aljazeeri, F. Tuma, Asynchronous group learning in learn from the learner approach: a learning object that enhances and facilitates distance self and shared learning, Ann. Med. Surg., vol. 67, no. July, p. 102535, 2021, doi: 10.1016/j.amsu.2021.102535.

[15] G.V. Davidson-Shivers, P.R. Lowenthal, K.L. Rasmussen, web-based learning: design, implementation and evaluation: second edition. 2017.

[16] W. Abdullah, Model blended learning dalam meningkatkan efektifitas pembelajaran, Fikrotuna, 2018, vol. 7, no. 1, pp. 855-866, doi: 10.32806/jf.v7i1.3169.

[17] D. Lalima, K. Lata Dangwal, Blended learning: an innovative approach, univers. J. Educ. Res., vol. 5, no. 1, pp. 129-136, 2017, doi: 10.13189/ujer.2017.050116.

[18] H. Simamora, Manajemen sumber daya manusia. STIE YKPN, 1995.

[19] M.S. Richards, efektivitas organisasi. Erlangga, 1980.

[20] M. Rifa'i, D.C. Wijaya, Dasar dasar manajemen mengoptimalkan pengelolaan organisasi secara efektif dan efesien. 2016. 